\title{
'He passed away because of cutting down a fig tree': The similarity between people and trees in Jewish symbolism, mysticism and halakhic practice
}

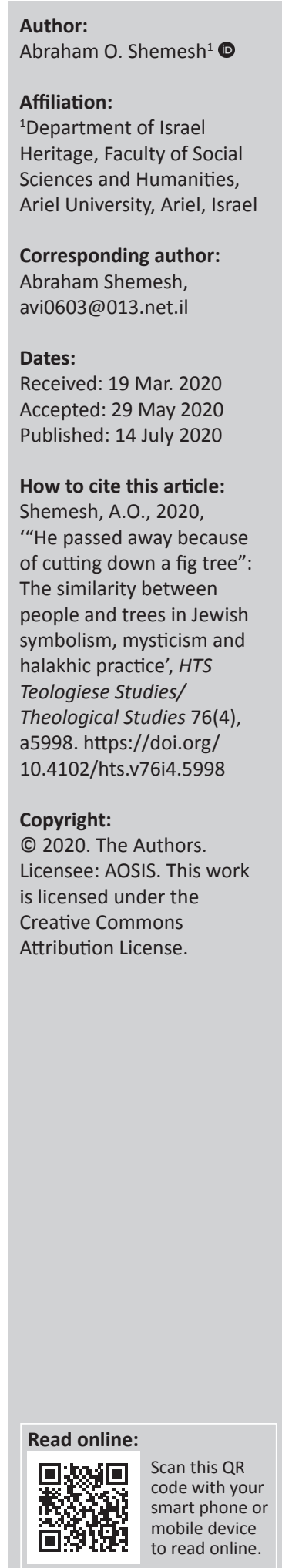

Comparing people to trees is a customary and common practice in Jewish tradition. The current article examines the roots and the development of the image of people as trees in Jewish sources, from biblical times to recent generations (Bible, classical rabbinical literature, medieval to modern rabbinic literature and popular culture), as related to the prohibition against destroying fruit trees. The similarity between humans and trees in the Jewish religion and culture was firstly suggested in biblical literature as a conceptual-symbolic element. However, since the Amoraic period (3rd-5th centuries CE), this similarity was transformed to a resemblance bearing mystical and Halakhic (Jewish Law) implications. Various sources in rabbinical literature describe trees as humans that may be spoken to or yelled at to produce fruit. Cutting down a tree was perceived by the rabbis of the Talmud (3rd-5th centuries CE) not only as an unethical act or vandalism, but also as a hazard: the death of the tree corresponds to the death of the person who resembles it. All societies, cultures and religions have a system of values and practices that are aimed at shaping people, society and the environment according to a certain worldview.

Contribution: The discussion in this article on the relationship between religion-culture and nature (plants) indicates how the Jewish religion shaped believers' attitude to the world of flora over the generations by transforming the man-tree comparison into one with binding and even threatening practical religious meaning.

Keywords: people and trees; cutting down trees; Jewish symbolism; halakhic practice; Jewish beliefs; Judah he-Hassid; Sefer Hassidim; popular beliefs; Naḥman of Braslav; Ba'al Shem Tov.

\section{Introduction}

Jewish sources (Bible, Talmud and rabbinic law) include a considerable number of references to ecological issues, such as environmental concerns (protecting natural vegetation from excessive grazing), organising the urban and agricultural environment as a convenient functional living space for humans, removing hazards from the urban space and others (see, e.g., Freudenstien 1970; Gerstenfeld 1998; Har Shefer 1994; Rakover 1993; Seidenberg 2015; Shemesh 2018a; Tirosh-Samuelson 2002; Zichel 1990). Ancient and later Jewish sources generally emphasised that the natural environment should not be ignored or neglected, and these sources contain a set of laws and prohibitions aimed at preserving and improving the world as the authors knew it (Har Shefer 1994:94-107).

Amongst these religious-ecological references, especially those that deal with vandalism related to plants, the comparison between people and trees is common. Over the generations, a reciprocation process developed - not only were people compared to trees, but trees were also compared to people, and not only theoretically but also as a realistic resemblance with practical meaning. Historically, some Jewish sages maintained a 'rational' position whereby they viewed damaging trees as ecologically prohibited but did not recognise an obliging religious element in the human-tree comparison. Indeed, to the best of our knowledge, the phenomenon whereby literary elements (metaphors, images and parables) are used to nurture and charge religious prohibitions is less customary in Jewish sources. In contrast, other sages who operated from a 'mystical' or 'irrational' perspective saw the literary human-tree symbolism as an element with more significant meaning, an insight that underlies the outlook whereby cutting down a tree entails personal danger to the person doing the cutting.

This article examines the roots and development of the image of people as trees as related to the prohibition against destroying fruit trees in a selection of representative historic Jewish sources, 
including the Bible, classical rabbinic literature, medieval to modern rabbinic literature and other evidence from popular culture. As will be shown, cutting down trees often received metaphysical-mystical significance as a result of the comparison of people to trees and trees to people. Destroying fruit-bearing trees is frequently described as harbouring a risk of death for the person who cuts the tree or his family, as this act is interpreted as resembling the 'murder' of human beings. This conception penetrated the world of Jewish law (halakha), and for this reason, halakhic authorities took a strict attitude towards cutting down fruit trees even for legitimate reasons.

However, this mystical interpretation was also countered by rationalist interpretations amongst other religious authorities, which rejected equivalencies between people and trees. By examining in detail an understudied element of Jewish thought, this article contributes to further discussions of the intersections between Judaism and ecological themes and practices.

\section{Humans, plants and Judaism: A general review}

Issues that involve nature and agriculture in general and plants in particular have occupied a prominent place in Jewish practice and thought over the generations. This is because agriculture had an important role in the economy of Jewish society in the Land of Israel in biblical, Mishnaic and Talmudic times, ${ }^{1}$ and as shown by Y. Felix, a scholar of Jewish botany, these agricultural systems were relatively well developed (Felix 1990:9-14). Furthermore, people in the ancient world lived in closer proximity to the sources of production than in modern society and natural resources had a major role in their nutrition, economy and commerce (Safrai 1994). Given the centrality of agriculture in Jewish society, it is unsurprising that various practical precepts mentioned in the Bible are associated with the world of nature and agriculture, for instance, allocating tithes (trumot and ma'asrot) from the crops to the priests and the poor (Lv 19:10; Dt 14:22) and the prohibition against working in the land in the Shmita year (Lv 25:4). ${ }^{2}$ These precepts stem from the agricultural religious nature of Jewish society.

Naturally, ancient Jewish society, for whom nature and agriculture were crucial for life and subsistence, held trees and groves in high regard, and, indeed, many works in rabbinic literature stress the significance of planting trees and voice praise for groves of fruit trees (Avot de-Rabbi Nathan 1945:34a; Leviticus Rabbah 1878:35b; and Felix 1994:29). Notably, in later periods, that is, the Middle Ages and the Modern Era, when many Jews no longer lived in an

1.The Mishnah was redacted by R. Judah the Prince at the end of the 2 nd century $C E$ The Mishnah is the first major written redaction of the Jewish oral traditions and laws. The Talmud is a collection of commentaries on and elaborations of the Mishnah and certain auxiliary materials. The term 'Talmud' refers to the Jerusalem Mishnah and certain auxiliary materials. The term Talmud' refers to the Jerusalem Talmud (Talmud and the collection known as the Babylonian Talmud (Talmud Bavli), compiled by the
Jewish sages of Babylonia (c. $500 \mathrm{CE}$ ).

2.Shmita is the seventh year of the 7-year agricultural cycle mandated by the Torah for the Land of Israel. During Shmita, the land is left to lie fallow and all agricultura activity is forbidden. agriculture-based economy, the natural world continued to occupy a central place in Jewish thought and philosophy as the ancient contents mentioned in the Bible as well as in the Mishna and Talmud literature remained an inseparable part of the Jewish culture and practice.

The proximity of ancient people with nature had philosophical and practical implications. The close contact with uncultivated plants, field crops, orchards and animals gave rise to the generation of theoretical, symbolic and philosophical contents of Jewish writings. In Jewish thought, the natural world, with its various components, serves as a means of observing God's power and amazing creations. God is mystical and hidden, whilst nature is a material manifestation of his deeds and his embodiment (Ps 8:4; Maimonides 2002:Yesode ha-Tora, 2.1; Shemesh 2007). The features, behaviour and appearance of components in the animal and plant world attest not only to the monumental stature of God himself but also constitute a foundation for theological-educational human values. The symbolism of the trees reflects humanity's moral and spiritual status and is used as a means of correcting and improving the individual and society at large.

Comparing people to trees or tree parts first appeared in biblical literature and seems to have developed because of the many similarities between people and trees. In Bible, one's children are called 'fruit of the womb', in analogy to the fruit of the tree (see, e.g., Dt 30:9). Water is a source of vitality for both people and trees (Ps 1:3), and just as trees and plants in general live a long life or wither, the life of humans and of human society is limited and transient as well (Is 51:2; 65.22; Ps 109:15).

In ancient Hebrew, there is a semantic association between picking fruit and a person who is 'picked' (dies), as well as between the gathering of fruit and of people who are 'gathered to their people', that is, who pass away (Gn 25:8; Nm 20:24; Jr 8:13; Mor 2004:126). Similarly, the phenomenon of 'personifying' trees is also a fairly customary biblical literary element, as, for example, in the parable of Jotham, where the trees 'speak' and express their opinions concerning human and social issues (Jdg 9:8-15). There are many other examples also (see Felix 1994:28-29).

In the ancient world, theological messages were conveyed through symbols, metaphors and similes that involved not only trees in general, but also specifically different types of plants, such as cedar, cypress, Juniper, oak, thorns, weeds and a variety of fruit trees such as date and grape vines (see Is 9:17; Ezk 19:10-14; Zch 14:17; Ps 37:2; 83:14; 128:3; Job 15:33; Ec 12:5). Various kinds of people in society are symbolised by plants with contrasting features. In biblical literature, plants that harm the fields, such as thorns and weeds, symbolise the wicked who are detrimental to society's moral resilience, while useful trees symbolise the righteous and honest ones who contribute to society (Ps 37:2, 129:6; Felix 1992:269-270). The wicked are likened to green weeds that dry out quickly, while the righteous are 
likened to tall, strong, enduring fruit-bearing trees, such as the cedar (Cedar of Lebanon, Cedrus libani) and the palm tree (Ps 92:13).

Plants were charged with symbolic meaning in early and late rabbinic literature as well. A conspicuous example includes the four species held on the Festival of Tabernacles - the citron, the date, the myrtle and the willow - which have been extensively symbolically interpreted. According to the midrash, the differences between the taste and fragrance of the four species symbolise people of diverse spiritual status within Jewish society. The citron that is edible and has a pleasant fragrance symbolises people on a high spiritual level who are scholars and who also perform good deeds ('people of action'); the date - whose fruit is edible but has no fragrance - symbolises scholars who are not people of action; the myrtle, which is inedible but has a pleasant fragrance - symbolises people of action who are not scholars; and the willow - which has neither edible fruit nor fragrance - symbolises simple people who are neither scholars nor people of action.

Holding the four species together symbolises the unity of the entire people with its various types, including the most simple (Leviticus Rabbah 1878:44b; Mandelbaum 1962 II:416). Another midrash identified in the four species, based on their morphological form, human body parts and the whole body (citron - a symbol of the heart; palm frond - the spine; myrtle - the eyes; and willow - the lips) (Leviticus Rabbah 1878:45a; Midrash Tanchuma 1883:Parashat Emor, $40 \mathrm{~b})$. Some have suggested that the four species symbolise water, the source of life for humans and human civilisation in general, as each of them is affiliated with a water-related habitat (Schaffer 1982:128-140).

\section{The concept of the similarity between humans and trees throughout Jewish history}

'Are the trees people'?

- the Biblical prohibition against cutting down trees in times of warfare

The first biblical source to compare people to trees is Deuteronomy 20:19-20, which tells about trees being destroyed during a siege by an attacking army. In the ancient world, the customary policy of leaving 'scorched earth' was practised in revenge against residents of a city who did not surrender when under siege (2 Ki 3:19; Kern 1999:64; Shemesh $2018 b)$. The biblical legislator objected to the destruction of plants and justified the prohibition by asking, ' $[a]$ re the trees people that you should besiege them?' (Dt 20.19).

Sages in the period of the Mishna and Talmud (1st-5th centuries CE) and medieval commentators in their analysis on this source presented various explanations for the prohibition against cutting down trees in times of war, and many focused on the differences between people and trees. The Aramaic translation ascribed to Jonathan ben Uziel gives the following interpretation: '[f]or the tree of the field is not like a person who can hide from you during a siege' (Ginzburger 1903:335). Unlike the inhabitants of the besieged city who can steal out from the city walls and lie in wait for the besieging soldiers, trees are stationary and cannot attack anyone. Rabbi Shlomo Yitzhakis (Rashi, North France 1040-1105), following Onqelos' Aramaic translation, interpreted the words as a question: is the tree like a person who takes part in a siege?! Trees are neutral in battle. An army that besieges a city may harm the inhabitants of the besieged city but not the trees that grow in the agricultural hinterland around the city as they are not enemies of the attacking army. In other words, trees are different from people and it is this difference that underlies the prohibition against damaging trees.

In contrast to Rashi, who claimed that trees are a 'neutral' party in war, R. Abraham Ibn Ezra (c. 1090-1164), born in Toledo, a commentator and philosopher, stresses that trees are a positive element and are beneficial to humanity as they are first and foremost a source of sustenance. According to him, the prohibition against destroying fruit trees derives from the same reason mentioned for the prohibition against pawning appliances for preparing food, as they are a source of vitality for human beings (Dt 24:6).

Rabbi Moses ben Naḥman (Ramban, Nahmmanides), a famous biblical and Talmudic commentator (Spain and Land of Israel 1194-1270), emphasises the benefits of trees even after the besieged city is occupied. This interpretation too seems to indicate the difference between people and trees. Whilst people might be aggressive, impulsive and a risk to one's life during battle, trees are an element adding life that might be beneficial after the battle also.

Hence, both the biblical legislator and later commentators explain the prohibition against cutting down trees in times of war in a rational, moral, utilitarian and ecological way and do not point out any mystical meaning or danger involved in doing so.

\section{The resemblance between people and trees in classic rabbinic literature: From symbolism to metaphysics}

Whilst according to the Scriptures, the similarity between people and trees is mainly theoretical, in classical rabbinic literature (composed from the 1st through 5th centuries CE), their association has mystical significance. This insight has several agricultural aspects and also relates to the uprooting of trees. Tannaitic and amoraic sources teach that, as part of practices for treating diseased trees, the ancients related to trees as people. An example of this is evident in the Jerusalem Talmud's explanation of the Tosefta, ${ }^{3}$ whereby in the Shmita year, it is forbidden to hang a branch of wild fig on a cultured

3.Like the Mishnah, the Tosefta is a compilation of the Jewish oral law, a source generated in the Land of Israel in the 2 nd century CE. 
fig because this helps its fruit develop (Tosefta Sheviit 1.9; Lieberman 1955:167, 1962:491).

\section{The Jerusalem Talmud explains (Sheviit 4.4):}

Tuvin (in the Tosefta version: Thuvin) should not be hung on figs: What should he do? Bring a cutting of a wild fig and hang it on [the fig], and say to it: This one bears fruit and you don't bear [fruit]. (p. 35b)

The farmer speaks to the tree that does not bear fruit as he would speak to another person. This appears to be an occult act intended to 'encourage' the cultured fig to bear fruit. The treatment is based on 'admonishment', similar to a person who does not fulfil his designation and must be stimulated using persuasive words (on the meaning of this reproof, see Lieberman 1963:76-77, and compare Löw 1924:I, 233 and Felix 1979:I, 255, who explain this as an agricultural act).

Another example of treating 'diseased' trees by means of human elements is brought in the Jerusalem Talmud: ' $[a]$ tree that destroys its fruit is painted with sigra [red paint] and piled with stones, and shouted at that it should bear fruit (Jerusalem Talmud, Ma'aser Sheni 5.1:55d). In other words, a tree that drops its fruit before it ripens or which bears fruit of poor quality or that are inedible would have its trunk painted red, stones would be placed on it, and it would be shouted at and shamed for not bearing fruit. The proposed agricultural treatment is not conventional but rather based on the world of the occult. The therapist relates to the tree as a person, 'torments' it with stones and admonishes it to bear fruit as it should.

As stated, treating trees as people is a method advocated in rabbinical literature also with regard to the issue of cutting down trees. The sages personified trees and compared the 'pain' of the destroyed tree to that of a person: ' $[w]$ hen people cut down the wood of the tree which yields fruit, its cry goes from one end of the world to the other, and the voice is inaudible' (Pirke deRabbi Eliezer 1972:118). The tree too groans when it is cut down, but unlike people who make a sound the tree's shout is mute. Some amoraim (the Talmudic rabbis who lived from the 3 rd through the 5th centuries CE) strayed from the rational foundations of the prohibition against cutting down trees and emphasised its underlying mystical hidden foundations, such as various dangers involved in this act.

The sages revealed the negative impact of destroying trees on the individual who does so: ' $[t]$ raders in market stands and those who breed small cattle [goats and sheep], and those who cut down beautiful trees [...] will never see a sign of blessing' (Babylonian Talmud, Pesachim 50b). Another source expands on the negative impact of this act and states its influence on the entire universe:

On account of four things are the luminaries in eclipse: On account of those who perpetrate forgeries, on account of those who give false witness; on account of those who rear small cattle in the land of Israel; and on account of those who cut down good trees. (Babylonian Talmud, Sukkah 29a)
In other words, cutting down trees causes an eclipse of the heavenly bodies, a natural phenomenon that portends bad events to come. (On solar and lunar eclipses in Judaism, see Am 8:9; J1 2:10; Bar-Ilan 2004:2031-2044; Greenfield \& Sokoloff 1989:201-214).

A different source in rabbinic literature cites another mystical aspect related to damaging trees - a person who cuts down a tree forfeits his life. The Talmud tells about the first-generation Eretz Israel amora Rabbi Hanina bar Hama, one of the greatest aggadic authorities, who explains his son's death as follows: 'Rabbi Hanina said: My son Shivhat did not pass away [for any reason] other [than] that he cut [down] a fig tree before its time' (Babylonian Talmud, Baba Kamma 91b). The Talmud permitted cutting down fruit trees when they produced little fruit and were not profitable (an old or diseased tree), for example, one kav of fruit $(2.2 \mathrm{~L})$ for a palm tree or a quarter kav (approximately $550 \mathrm{cc}$ ) for an olive tree (Babylonian Talmud, Baba Kamma 91b and compare Maimonides 2002:Hilkhot Melachim 6:10).

It is to be assumed that Shivhat deviated from these quantities, and therefore, Rabbi Hanina associated his death with the unjustified cutting down of a fruit tree. Rabbi Hanina's interpretation clearly reflects the belief that harm to a tree is paramount to harming a person. One who cuts down a tree is punished by death, similar to the law regarding a murderer, in a manner reminiscent of the 'measure for measure' principle.

The story of the death of Shivhat, son of Rabbi Hanina, spread amongst the amoraim, and they were convinced that cutting down trees unnecessarily can cause death. The Talmud relates that the fourth-generation Babylonian amora Rabba bar Rabbi Hanan refused to cut down one of his palm trees that was causing damage to the grove of his neighbour, Rabbi Yosef, although strictly speaking this is permissible, because of the fatal risk cited by Rabbi Hanina.

The identification between trees and persons with regard to one's fate arises from the unusual story concerning the death of the son of third- or fourth-generation Eretz Israel amora, Rabbi Yossi d'min Yukrat. This story has been interpreted from various angles, such as the recurring element of a father who kills his son (located in various mythologies), intervention through miracle, the precept of benevolence and its rewards, improper behaviour of a Talmudic sage and so on (see, e.g., Fraenkel 1981:36-40; Katz \& Rosenson 2000:161-177; Kosman 2002:52-57). Beyond these other themes, I shall emphasise the reflection of the tree-person association as a recurring element in comparison to the story of the death of Shivhat, son of Rabbi Hanina. However, firstly, I shall introduce the story itself:

Once R. Yossi had day-laborers [working] in the field.

Night set in and no food was brought to them and they said to his son, 'We are hungry'. 
Now they were resting under a fig tree and he exclaimed: 'Fig tree, fig tree, bring forth thy fruit that my father's laborers may eat.

It brought forth fruit and they ate.

Meanwhile the father came.

He said to them: 'Do not bear a grievance against me; the reason for my delay is because I have been occupied up till now on an errand of charity'.

The laborers replied: 'May God satisfy you even as your son has satisfied us'. Whereupon he asked: 'Whence?'

They told him what had happened.

Thereupon he said to his son: 'My son, you have troubled your Creator to cause the fig tree to bring forth its fruits before its time, may you too be taken hence before your time!' (Babylonian Talmud, Taanit 24a).

The common use of the verbs 'picked' and 'gathered' in the vegetative and human world has been described above. As stated by the scholars Fraenkel, Katz and Rosenson, the narrator uses the verb 'gathered' to stress the dimension of measure for measure - as a result of gathering, the son was gathered to his people, that is, died (Fraenkel 1981:36-40; Katz \& Rosenson 2000:52-57).

The story encompasses an ironic question - did Rabbi Yossi min Yukrat not cause his Maker to go to the problem of causing the miracle of killing the son? Is the son's miracle of producing the figs any less than the miracle that he himself seeks? This is undoubtedly sharp criticism of this sage, who in order to attempt a dubious religious justification causes the death of his son. Nonetheless, another explanation for the occurrences is possible based on the nature of the fig tree and the comparison between people and trees.

Following Fraenkel's emphasis on the story's 'time dimension', it is evident that a parallelism is formed here, hastening the ripening of the fig's fruit and, as a result, hastening the son's death. According to the view of Rabbi Yossi min Yukrat, causing a miracle means controlling the timing of a natural phenomenon and that was his son's sin. As he sees it, the prohibition against interfering with nature and with realistic time is a supreme value that surpasses values of charity and feeding the hungry.

The nature of the fig tree is an important part of the story as the fruit of this tree, in contrast to many others, ripens at different times, and this is not given to human intervention. Whilst the fruit of other trees is gathered all at once, figs must be gathered one by one only upon ripening $(\operatorname{Pr} 27: 18$; Mishnah, Pea 1.4-5). This recurring element also appears in the story of Shivhat who cut down a fig before its time, who intervened in nature and did not let the tree live its normal life span. Hence, according to the person-tree identification, intervention in the tree's life span (cutting it down early in the story of Shivhat) or hastening the picking of the fruit, which is a regular seasonal process (in the story of Rabbi Yossi min Yukrat), constitutes a danger to human life. Thus, in both cases, the 'rationale' underlying Rabbi Hanina's words and Rabbi Yossi min Yukrat's curse derives from the belief in a mystical connection between human life and the life of the tree, although it is difficult to find a rational connection between these elements.

\section{Cutting down of trees from medieval to modern Jewish literature}

In medieval literature, we encounter two approaches to cutting down trees. One, the rational, is led by the Maimonides, and the other, metaphysical, is led by Rabbi Judah he-Hassid. The Sephardic Jewish physician, philosopher and halakhic man, Rabbi Moses ben Maimon (Maimonides, Spain and Egypt, 1138-1204), as a rationalist, mentioned in his halakhic compilation, Mishneh Torah, the prohibition against cutting down trees but did not refer to the 'mystical danger' involved. On the other hand, he expanded the prohibition against vandalism to times of peace and to other things aside from trees. Maimonides writes (Maimonides 2002:Hilkhot Melachim 6):

We should not cut down fruit trees outside a city nor prevent an irrigation ditch from bringing water to them so that they dry up, as Deuteronomy 20:19 states: 'Do not destroy its trees'. Anyone who cuts down such a tree should be lashed. This does not apply only in a siege, but in all situations. Anyone who cuts down a fruit tree with a destructive intent, should be lashed.

Nevertheless, a fruit tree may be cut down if it causes damage to other trees or to fields belonging to others, or if a high price could be received for its wood. The Torah only prohibited cutting down a tree with a destructive intent [...] This prohibition does not apply to trees alone. Rather, anyone who breaks utensils, tears garments, destroys buildings, stops up a spring, or ruins food with a destructive intent transgresses the command 'Do not destroy'. However, he is not lashed. Instead, he receives stripes for rebellious conducts instituted by the Sages. (pp. 5-10)

Maimonides claims that nothing should be harmed unnecessarily or unjustifiably, but when there is a need, whether agricultural or financial, it is permitted to cut down fruit trees, such as when the tree is harmful to other trees in its vicinity or when its trunk is more lucrative than the fruit.

Rabbi Judah he-Hassid, one of the most prominent amongst the group of 13th-century Ashkenaz Hassids, relates to cutting down trees in his work Sefer Hassidim. This book is a guide to a full ethical Jewish life where he presents a radical and demanding religious and social vision of a group of hassids. (On Rabbi Judah he-Hassid and his book Sefer Hassidim, see Dan 2006:8, 61; Scholem 1974:80-106.) The book contains laws, customs and ethics and deals with a wide array of topics from everyday life paralleled with popular beliefs and miraculous deeds. It is considered a historical record that sheds light on the life of Jews and Jewish ideology in late 12th and early 13th century Europe (Dan 2006:31). 
Rabbi Judah forbids cutting down fruit trees unequivocally, with no caveats or permits. He writes laconically, ‘[a] fruit bearing tree should not be cut down' (he-Hassid 1957:ch. 45, p. 24). Rabbi Judah he-Hassid, similar to other places in his compilation, does not mention his source and he probably derived the idea of the danger involved in cutting down trees from the story of Shivhat, son of Hanina. As stated by Joseph Dan, the Mussar doctrine formulated in Sefer Hassidim spread in subsequent centuries and joined the Mussar doctrines that emerged concurrently in Spain, whilst the mystic doctrine of Ashkenaz Hassidim merged with Kabbalistic mysticism in the late 13th century. As described in greater detail below, Rabbi Judah he-Hassid's ruling in the matter of cutting down trees had a significant impact on subsequent adjudicators.

Notably, Rabbi Judah he-Hassid's ruling is not compatible with his previous ruling: ' $[a]$ tree that gives fruit twice a year should be cut down and should not be left growing at all' (heHassid 1957:ch. 44, p. 24).

This ruling is very surprising because it directly contradicts his subsequent decision as well as the biblical prohibition and the words of the Talmud, and many tried to find an explanation for it (Sperber 1992:I, 9-16). This ruling also appears to have originated from a popular irrational belief stemming from the outlook whereby a tree that gives fruit twice a year is 'hazardous' because it deviates from the natural ways.

The recommendation to cut down the tree, according to Rabbi Judah he-Hassid, constitutes a 'prevention of the danger' that might occur by allowing this deviant tree to grow, according to the principle that averting danger to health takes priority over ritual laws (hamira sakanta me-isura; see Babylonian Talmud, Hullin 10a).

The danger involved in harming trees was also mentioned in late sources. Rabbi Nahman of Braslav (Ukraine, Russian Empire 1772-1810) warns, ‘[a] person should take care not to cut down a tree before its time has come as this is detrimental to raising sons' (Nahman of Braslav 1927:28). Rabbi Nahman does not warn that the sons might die, rather that their upbringing might be harmed, although he may have meant their death.

He does not link the harming of the tree to the death of the perpetrator, as in the case of Rabbi Hanina's son, but rather to the perpetrator's children. This difference is strongly reminiscent of the similarity between fruit-bearing trees and human beings whose children are their fruit. In fact, Rabbi Nahman did not define the destruction of the tree as a halakhic prohibition, rather he emphasised the danger involved, which may be related to the broader theme of his book, containing as it does recommendations and instructions related, amongst other things, to the world of metaphysics and the unknown.

\section{From the mystical to the practical: Cutting down trees in the Responsa literature}

The Responsa literature ${ }^{4}$ includes various halakhic questions related to cutting down trees in daily life. Most of the discussions focus on two topics: the need to cut down a tree versus the prohibition of 'do not destroy' (bal tashit) which was mentioned in the Babylonian Talmud (Kidushin 32a), that is, the moral and ecological value of leaving the tree as is versus the mystical concern of the risk of death. The adjudicators do not state explicitly that the cause of danger is the resemblance between trees and people, rather they cite the story of Shivhat's death as a result of uprooting the tree. In any case, it is clear that the structuring of the similarity between people and trees bore fundamental meaning in halakhic rulings.

Rabbi Yair Haim Bacharach (Moravia 1639-1702) discusses a case in which the crown of a tree that grows in a yard blocks a window and prevents the entrance of light. The question asked was whether it is permissible to cut down the tree and whether this would not constitute a transgression of the 'do not destroy' prohibition and raise a concern of danger. Rabbi Bacharach determines that if there is a need to cut down the tree, it is not considered destruction, for example, if the tree is detrimental to the growth of a more important fruit tree (following the approach of the Maimonides above), all the more so when the crown prevents the entrance of light or blocks the window. In any case, he says that it is preferable to trim the tree's branches from time to time, despite the problem involved, rather than to cut down the entire tree, as cutting down a tree is a biblical prohibition and a hazardous act (Bacharach 1896:siman 195). Although according to the Maimonides's approach cutting down the tree is justified as it stems from a need, the mystical argument remains a concern.

A similar question was asked about Rabbi Jacob Emdin (Germany 1697-1776) with regard to uprooting a vine to expand a synagogue. Rabbi Emdin answers that the prohibition is valid only if the act is performed in a way that constitutes 'destruction', that is, for insufficient cause, but it is permissible for an important need such as erecting a synagogue. On principle, trees may be cut down even to build a residential house, all the more so to fulfil the precept of expanding a synagogue. Nevertheless, because of the concern for the life of one who cuts down a fruit tree, it is better to uproot the vine with its roots intact and plant it elsewhere (Emdin 1884:vol 1, siman 76. The same solution was offered by Rabbi Moshe Sofer in his responsa, Hatam Sofer 1958:vol. 2, Yore Dea, siman 102, 34b). Hence, Emdin too was concerned about the danger involved, and therefore, in conclusion, chose not to rule according to Maimonides.

4.The Jewish Responsa literature contains decisions and halakic rulings given by legal scholars (Rabbis, adjudicators) in response to questions addressed to them. On this literature, see Soloveitchik (1990). 
Following the words of Rabbi Judah he-Hassid, other adjudicators were also concerned about the danger involved in cutting down trees. Rabbi Haim Yosef David Azulai (Jerusalem 1724-1806), known as the Hida, claimed that Rabbi Judah he-Hassid forbade cutting down fruit trees even for good cause when permitted by halakha because of the danger involved in cutting down trees (Azulai 1886:vol I, siman 23, 27a). The discussion indicates that Rabbi Judah he-Hassid's words settled the Hida's doubts on this issue, and therefore, he recommends, when necessary, to have the tree cut down by a non-Jew. The chief rabbi of İzmir, Rabbi Haim Palagi (1788-1868) in contrast, was stricter and forbade cutting down a tree even by a non-Jew, claiming that this is hazardous and no leniency is in order. In his opinion, it is preferable in such a case to extract the tree from the ground with its roots and plant it elsewhere (Palagi 1873:siman 24, 32a).

Over the generations up to the present time, the concern of harming trees grew and was raised even in cases when permission was usually given, such as to increase the tree's growth or to build a sukkah for the Festival of Sukkot. Moreover, some were concerned that the danger existed when pruning branches as well and not only when cutting down the entire tree. Rabbi Ovadia Yosef (Iraq and Jerusalem 1920-2013), the Sephardi Chief Rabbi of Israel (1973-1983) and one of the prominent adjudicators in the recent generation, discussed the question of whether it is permissible to prune the branches of fruit trees to use as a topping (sechach) for tabernacles on the Festival of Sukkot. He presented several justifications for permitting this. The prohibition of 'do not destroy' refers to cutting down the entire tree, whilst pruning the branches only strengthens the tree and even encourages its growth. Moreover, several sources in the Scriptures and in rabbinic literature provide proof that the ancients used the branches of fruit trees, such as olives and dates, to build tabernacles (Neh 8.15) and vegetative matter from fig and nut trees to operate the altar in the temple (Mishnah, Tamid 2.3).

Hence, for the purpose of fulfilling a commandment, it is permissible to prune fruit trees; however, it is preferable to have it done by a non-Jew (Yosef 1985:vol. 5, siman 45).

Rabbi Yosef's arguments can be supplemented by rabbinic literature, which mentions the various pruning acts carried out in fruit groves, such as trimming vines, cutting the trunk close to the ground with the possibility of renewal (gemima), pruning (zerida) and so on, and it appears that those Rabbis who were farmers saw these operations as important agricultural acts and did not take a strict attitude. (On these agricultural acts, see Felix 1994:55-60.) Moreover, cutting down trees was a fundamental part of people's everyday routine, for instance, for building purposes, for the wood industry, for heating and stoking fires, and so on (Avitzur 1972:242-243). Hence, a complete prohibition against pruning tree branches is a radical and strict approach that disregards basic human needs.

\section{The association between people and trees in popular culture and Hassidic literature}

In various Jewish communities, there is a popular belief, based on the association between people and trees, that when trees near a house are uprooted, for instance, in a storm, it is considered a bad omen for the people living in the house. Although it is not assumed that the people in the house caused this curse, the tradition continues that the number of dead in the house will equal the number of trees uprooted (Bergman 1953:38). The symbolic and the mystical belief in the people-trees association was also evident within popular medicine. I shall focus on two prominent examples from the literature of folk remedies and from Hassidic literature in recent centuries. In his book Sefer Mareh ha-Yeladim, Rabbi Raphael Ohana (Morocco and Israel 1850-1902) advises many recommendations and remedies for treating barrenness and enhancing fertility. One of the remedies for the medical problem is described as follows:

Take a long piece of paper and dip it in her [the woman's] menstrual blood and go to a tree laden with fruit and put the paper in a hole or crack in the tree. And if there is no hole or crack make a hole and put the mentioned paper in it and say 7 times: 'Tree tree I give you my sickness and you give me your fruit'. And you shall not go to the tree again at all. (Ohana 1990:82)

The ritual suggested by Ohana includes practical and verbal acts:

1. Inserting a piece of paper saturated with menstrual blood in the tree's trunk or branches - Ohana stresses that a tree laden with fruit should be chosen, that is, one with a feature of increased fertility so that it will have an effect on the barren woman.

2. Replacing or substituting the woman's barrenness with the fruit of the tree - the petitioner appeals to the tree as one speaks to a person and orders it seven times (for purposes of emphasis and reinforcement) to carry out an 'exchange'. The tree shall stop producing fruit or its produce will diminish, while the woman will acquire its fertility feature.

The suggested treatment of inserting menstrual blood in the tree and the act of substitution are an example of the 'law of similarity' and the 'law of contagion', which the social anthropologist and folklorist James George Frazer (Scotland 1854-1941) suggested were foundations of magic activity. According to the 'law of similarity', that which is similar or identical affects that which is similar or identical to it or establishes it.

Trees and people are similar in their fruit and embryos, so trees might have an impact on human fertility.

According to the Jewish laws of purity and impurity, menstrual blood is impure. However, generally, Jews did not avoid using impure or unclean remedies even for patients whose life is not in danger (Shemesh 2014, 2019). 
Inserting the blood in the tree creates contact ('the law of contagion'), a magic operation facilitates the transferring of qualities or powers that exist within objects, natural components or people to other elements.

Treating the sick by using practices involving trees is an element that appears in Hassidic literature too. Rabbi Israel Ba'al Shem Tov ('Besht', Ukraine c. 1700-1760), founder of the Hassidic movement, was known as a popular healer who saved many people from illness and death (on Rabbi Israel Ba'al Shem Tov as a healer, see Etkes 2005:7-45). The Hasidic rebbe Rabbi Israel Friedman of Ruzhin (1796-1850) tells about the treatment that the Ba'al Shem Tov suggested to a young man whose life was at risk (Zak 1906):

Maran the holy man related the story of the Ba'al Shem Tov of blessed memory in the world to come, that one time there was a matter of one whose life was at risk, a single child and very [sick] [...] and he instructed that a candle of wax be made and [he] travelled to the woods and attached the candle to a tree and some other matters and Kabbalistic meditations [...] and achieved salvation, with God's blessed help. (p. 12a)

The story before us contains the element of the human-tree resemblance. Attaching the candle to the tree was not intended to produce light in the darkness, rather it symbolises the connection between the candle - the soul ('God's candle is the human soul') and the tree, that is, the young man's sick body. The sick person was in a very grave condition and his soul had almost left his body. To reconnect the soul with the body, the Ba'al Shem Tov recommended 'attaching' the candle to the tree and thus reviving the sick human's life.

\section{Summary and discussion}

The similarity between humans and trees, first suggested in biblical literature as a conceptual-symbolic element, was transformed in the time of the amoraim and henceforth to a resemblance bearing mystical and halakhic implications. Various sources in rabbinic literature describe trees as humans that may be spoken to or yelled at to produce fruit. The most conspicuous Talmudic source in the structuring of the realistic human-tree or tree-human resemblance is Rabbi Hanina's interpretation of his son's death as a result of the unjustified cutting down of a tree. This story became the most significant factor in the discussions of medieval and modern sages concerning issues related to uprooting trees. Cutting down a tree was perceived not only as an unethical act or vandalism, but also as a personal hazard because of the resemblance between people and trees.

The approach to the human-nature relationship in the Garden of Eden story (Gn 1) is rational. The human, who is an intelligent creature, controls the environment and has permission to utilise the plant and animal world for his various needs. Then again, he is obliged to display an awareness of the environmental fabric and to avoid harm to the ecosystem (such an approach also exists in rabbinic literature; see Ecclesiastes Rabbah 1878:20a and Gerstenfeld 2004:45; Tirosh-Samuelson 2017). The mystical prohibition against cutting down trees is indeed not connected to the realistic world, but it too identifies the danger of harming nature. Nevertheless, whilst according to the rational approach, harm to a tree does not necessarily result in harm to people (e.g. in the case of controlled tree felling), and according to the mystical approach, harm to (even a single) fruit tree is hazardous and might harm the person who damaged the tree.

In the Middle Ages, two approaches were formed with regard to cutting down trees. The rational attitude of Maimonides was that in time of need, it is permissible to cut down fruit trees, for instance, when the tree does not produce a worthy quantity of fruit or when its trunk is more beneficial than its fruit. In contrast, Rabbi Judah he-Hassid argued that fruit trees should not be pruned, based on the mystical perception of the dangers this entails. Although Maimonides was a prominent adjudicator with weighty halakhic opinions, the concern embodied by Rabbi Judah's words underlies many of the halakhic discussions on the issue of uprooting trees. Rabbi Judah's view influenced many later thinkers; indeed, many of the later adjudicators take his opinion into account despite their knowledge of Maimonides's lenient opinion. Several adjudicators tried to solve the concern of the danger entailed by cutting down trees and permitted their uprooting by non-Jews; however, others objected to this solution. The concern of the danger involved in harming trees reached radical levels in later generations so much so that some Jewish sages even feared pruning the branches of fruit trees for agricultural purposes (to encourage growth) or to build tabernacles on the Festival of Sukkot.

The similarity between people and trees not only generated concerns of danger upon cutting down fruit trees but also informed popular medicine. Popular healers, as well as sages from the Hassidic movement, utilised trees in their therapeutic practices, for example, for curing barrenness or for curing the mortally sick by the technique of attaching a candle to a tree as a symbol of connecting the soul, symbolised by the candle, to the tree that symbolises the human body.

The Jewish faith deals not only with the relationship between humans and God and humans' private religious duties. As a religion that shapes the life routine of its believers, it also suggests a series of laws, prohibitions and guidance with regard to the believer's material environment. In other words, Judaism ascribes significance not only to the mystical and spiritual dimensions of humanity but also to the material system that constitutes the foundation of human existence. Jewish law holds a dual view of people's attitude towards plants. On the one hand, humans may and should make use of natural components, and on the other hand, it is forbidden to destroy or show lack of consideration for the various organisms (Har Shefer 1994:57).

According to the rational approach reflected in several literary sources, destruction of vegetation may have a detrimental effect on human society, although not 
necessarily on a specific person. In contrast, according to the mystical halakhic conception, destruction of trees involves a different hazardous aspect - a personal death threat to a person who cuts down a tree. The danger involved in destroying trees is a very real element in the literature on this issue. It is difficult to know to what degree this contributed to actual preservation of plants by Jews over the generations, but in any case, it has to be assumed that the personal threat contained in this approach had more of a deterring effect than did the rational approach.

The scientific studies conducted to date on ecology as viewed in Judaism indeed dealt with various aspects related to the environment, but only to a relatively limited degree with human-tree similarity and its impact on the prohibition against destroying trees. The contribution of the current article to the discussion of this issue focuses on two spheres:

1. It indicates that the human-tree similarity exceeded the theoretical literary boundaries and that the similarity between people and trees reached practical domains as well. Moreover, this similarity received new meaning not only concrete but also threatening.

2. Most of the studies focused on the attitude of Jewish law to topics of environmental hazards, such as damages wrought by industry, noise, smell and excess grazing, as well as the prohibition Bal tashchit that forbids any destroying and wasting, although from a purely ecological perspective, namely, damage to the environment and forbidding any destroying and wasting. The context for this may have been the attempt to present the Jewish view on this important area that was placed on the agenda of modern society following global processes of exploitation and harm to the environment as a result of industrialisation, increased population on a global level, deforestation for agricultural purposes and so on.

This article reveals an aspect of the destruction of trees that is less familiar in Jewish discourse and that has not received research attention to date, namely, the assimilation of ancient popular Jewish beliefs in halakhic considerations and even amongst modern adjudicators. Beliefs regarding the irrational danger involved in cutting down trees had a significant impact on the shaping of Jewish law in all generations and this concern has implications for the practices of observant Jews at present as well.

\section{Conclusion}

This article focused on presenting the religious-ecological prohibition against cutting down trees as a practical manifestation of the tree-human similarity. Whilst discussing this issue, new research directions were revealed, indicating embodiment of the human-plant similarity, particularly marriage and fertility customs documented in Jewish literature from the Mishna and Talmud period and so on.
One example of this is the custom of planting a tree upon the birth of a baby, and subsequently to use that tree to build the marriage canopy for his or her marriage day (Babylonian Talmud, Gittin 55b). Other examples are the custom of throwing wheat at a groom and bridge during the marriage ceremony as a blessing and with the wish that they may multiple and be fertile as wheat, where a single kernel develops into a stalk with a large number of kernels (Babylonian Talmud, Berakhot 50b; Simhah of Vitri 1923:589), as well as the ancient ceremony of 'transferring one's sins' (kaparot - expiation) to a potted plant (Babylonian Talmud Shabbat $81 \mathrm{~b}$ ). The concept underlying these customs, as well as their evolvement and shaping, requires a separate discussion and it shall be expanded elsewhere.

\section{Acknowledgements Competing interests}

The authors have declared that no competing interest exist.

\section{Author's contributions}

I declare that I am the sole author of this research article.

\section{Ethical consideration}

This article followed all ethical standards for a research without direct contact with human or animal subjects.

\section{Funding information}

This research received no specific grant from any funding agency in the public, commercial or not-for-profit sectors.

\section{Data availability statement}

Data sharing is not applicable to this article as no new data were created or analysed in this study.

\section{Disclaimer}

The views and opinions expressed in this article are those of the authors and do not necessarily reflect the official policy or position of any affiliated agency of the authors.

\section{References}

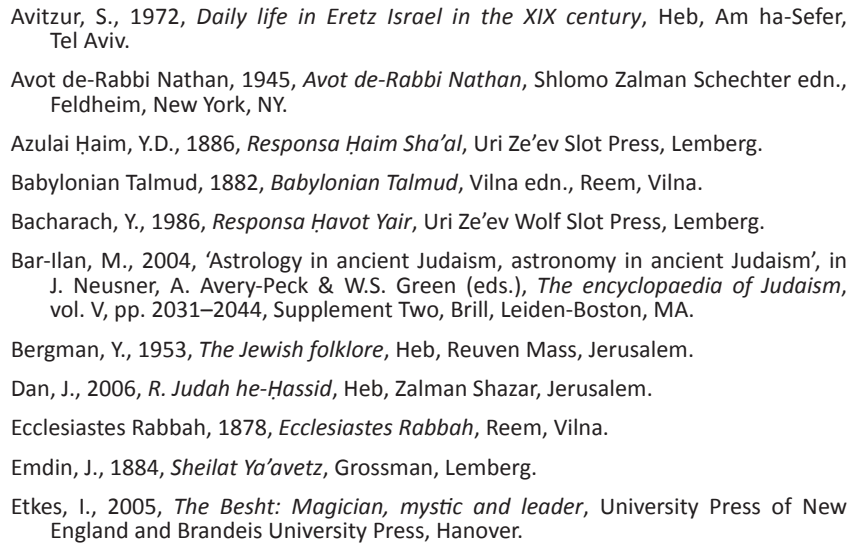


Felix, Y., 1979, Yerushalmi Masechet Sheviit, Heb, Ztur Ot, Jerusalem.

Felix, Y., 1990, Agriculture in Eretz-Israel in the Period of the Bible, Mishnah and the Talmud, Heb, Reuven Mass, Jerusalem.

Felix, Y., 1992, Nature and land in the Bible: Chapters in Biblical ecology, Heb, Reuven Mass, Jerusalem.

Felix, Y., 1994, Fruit trees in the Bible and Talmudic literature, Heb, Reuven Mass, Jerusalem.

Fraenkel, Y., 1981, Studies in the spiritual world of the aggadic narrative, Heb, Hakibbutz Hameuchad, Tel Aviv.

Freudenstien, E.G., 1970, 'Ecology and the Jewish tradition', Judaism 19(4), 406-414.

Gerstenfeld, M., 1998, Judaism, environmentalism and the environment: Mapping and analysis. The Jerusalem Institute for Israel Studies, Reuven Mass, Jerusalem.

Gerstenfeld, M., 2004, 'Approaches to environmental issues: A survey', Bekhol Derakhekha Daehu (B.D.D.) 14, 23-45.

Ginzburger, M., 1903, Translation of Yonatan ben Uziel on the Torah, Kaloari, Berlin.

Greenfield, J.C. \& Sokoloff, M., 1989, 'Astrological and related Omen texts in Jewish Palestinian Aramaic', Journal of Near Eastern Studies 48(3), 201-214. https://doi. org/10.1086/373393

Har Shefer, Z., 1994, Ecology in Jewish heritage, Shaanan College Publication, Haifa.

He-Hassid, Judah, 1957, Sefer Hassidim, Reuven Margaliot edn., Mosad ha-Rav Kook, Jerusalem.

Jerusalem Talmud, 1523, Jerusalem Talmud, Venice edn., Daniel Bomberg, Venice.

Katz, M. \& Rosenson, I., 2000, 'O fig tree, give forth your fruit: The stories of Rabbi Yossi of Yukrat', Derech Agaddah 3, 161-177.

Kern, P.B., 1999, Ancient Siege Warfare, Indiana University Press, Bloomington, IN.

Kosman, A., 2002, Men's tractate: Rav and the Butcher and other stories, Heb, Keter, Jerusalem.

Leviticus Rabbah, 1878, Leviticus Rabbah, Reem, Vilna.

Lieberman, S., 1955, Tosefta, Jewish Theological Seminary, New York, NY.

Lieberman, S., 1962, Tosefta ki-Pshuta: Zeraim, Jewish Theological Seminary, New York, NY.

Lieberman, S., 1963, Greek and Hellenism in Jewish Palestine, Heb, Mossad Bialik, Jerusalem.

Löw, I., 1924, Die Flora der Juden, R. Löwit, Vienna-Leipzig.

Maimonides, M., 2002, Mishneh Torah, ed. Shabtai Frankel, Hotza'at Shabse Frankel Ltd, Jerusalem.

Mandelbaum, B., 1962, Pesikta de-Rav Kahana, Jewish Theological Seminary of America, New York, NY.

Midrash Tanchuma, 1883, Midrash Tanchuma, Levine-Epstin, Vilna.

Mishnah, 1952, Mishnah, Hanoch Albeck edn., Mossad Biyalik and Dvir, Jerusalem.

Mor, Y., 2004, 'Study of the story of R. Yossi min Yukrat', in M. Katz (ed.), Aggadic literature: Collection of rabbinical stories for teaching literature, Heb., vol. II, pp. 125-130, Efrata College and Ministry of Education and Religious Education Administration, Jerusalem.
Naḥman of Braslav, 1927, Sefer ha-Midot, Traklin, Warsaw.

Ohana, R., 1990, Sefer Mareh ha-Yeladim, Shlomo Cohen edition, Jerusalem.

Palagi, H.., 1873, Responsa Haim be-Yad, Binyamin ben Zion Press, Izmir.

Pirke deRabbi Eliezer (Attribute to R. Eliezer ben Horkenos), 1972, Haim Meir Horowitz edition [Venice manuscript, 1544], Makor, Jerusalem.

Rakover, N., 1993, Environmental issues, theoretical and legal aspects of Jewish sources, Moreshet ha-mishpat be-Israel, Jerusalem.

Safrai, Z., 1994, The economy of Roman Palestine, Routledge, London.

Schaffer, A., 1982, 'The agricultural and ecological symbolism of the four species of Sukkot', Tradition: A Journal of Orthodox Thought 20, 128-140.

Scholem, G., 1974, Major trends in Jewish mysticism, Schocken Books, New York, NY.

Seidenberg, David M., 2015, Kabbalah and Ecology, Cambridge University Press, Cambridge.

Shemesh, A.O., 2007, 'Nature and landscapes in the book of Psalms: Observations of the relation between man, nature and God', in U. Zur (ed.), The first convention of the Israel Heritage Department: Psalms, pp. 99-121, The Academic College Judea and Samaria, Ariel.

Shemesh, A.O., 2014, 'Did Jews avoid using products made of pigs as medical materials? "And the Swine [...] It is Unclean Unto You" (Deut. 14: 8)', Vesalius: Acto Internationalia Historiae Medicinae 20(2), 89-94.

Shemesh, A.O., 2018a, "'For the public's improvement and for the benefit of the town": Correspondence between Rabbi Kuk and residents of the Moshavot in Eretz Israel on ecological and environmental matters', Modern Judaism 38(1), 44-74. https://doi.org/10.1093/mj/kjx040

Shemesh, A.O., 2018b, 'Holiness, war, and peace: Ancient Jewish traditions concerning the landscape and ecology of Jerusalem and its environs in the second temple period', Religions 9(8), 1-17. https://doi.org/10.3390/rel9080241

Shemesh, A.O., 2019, 'Two responsa of R. Samson Morpurgo on non-kosher medicines: Therapy vs. Jewish halakic principles', Journal for the Study of Religions and Ideologies 18(52), 3-16.

Simhah of Vitri, 1923, Mahzor Vitri of Simha ben Shmuel mi-Vitri, Simon ha-Levi Horowitz edn., Mekitze Nirdamim, Nürnberg.

Sofer, M., 1958, Responsa Hatam Sofer, Joshua Grossman Press, New York, NY.

Soloveitchik, H., 1990, The use of responsa as a historical source, Heb, Zalman Shazar Center \& The Hebrew University, Jerusalem.

Sperber, D., 1992, The customs of Israel, vol. 1, Heb, Mossad ha-Rav Kook, Jerusalem.

Tirosh-Samuelson, H., 2002, Judaism and ecology: Created world and revealed world, Harvard University Press, Cambridge.

Tirosh-Samuelson, H., 2017, 'Jewish environmental ethics: The imperative of responsibility', in J. Hart (ed.), The Wiley Blackwell companion to religion and ecology, pp. 179-94, John Wiley \& Sons, Hoboken, NJ.

Yosef, O., 1985, Responsa Yehave Da'at, Hazon Ovadia, Jerusalem.

Zak, R., 1906, Keneset Israel, Edelstein Press, Warsaw.

Zichel, M., 1990, Environmental (Ecological) Issues in Jewish Sources, Heb, Responsa Project, Bar Ilan University Press, Ramat Gan. 